\title{
1 Agility and sustainability: A qualitative evaluation of COVID-19 \\ 2 Non-pharmaceutical Interventions (NPIs) in the UK logistics \\ 3 sector
}

4 Hua Wei ${ }^{1,4 *}$, Sarah Daniels ${ }^{1,4}$, Carl A. Whitfield ${ }^{2,4}$, Yang Han ${ }^{2,4}$, David W. Denning ${ }^{3,4}$, Ian Hall ${ }^{2,4,5}$, Martyn Regan ${ }^{1,4,6}$, Arpana Verma ${ }^{1,4}$, and Martie van Tongeren ${ }^{1,4}$

${ }^{1}$ Division of Population Health, Health Services Research \& Primary Care, School of Health

7 Sciences, University of Manchester, Manchester, England;

$8 \quad{ }^{2}$ Department of Mathematics, University of Manchester, Manchester, England;

$9 \quad{ }^{3}$ Division of Infection, Immunity \& Respiratory Medicine, School of Biological Sciences,

10 University of Manchester, Manchester, England;

$11{ }^{4}$ Manchester Academic Health Science Centre, University of Manchester, Manchester,

12 England;

$13{ }^{5}$ Public Health, Advice, Guidance and Expertise, UK Health Security Agency, London,

14 England;

$15{ }^{6}$ National COVID-19 Response Centre, UK Health Security Agency, London, England

16 * Correspondence:

17 Hua Wei, hua.wei@manchester.ac.uk

18 Keywords: COVID-19, rapid response, logistics sector, delivery workers, non19 pharmaceutical interventions

\section{Abstract}

Background: The emergence of SARS-CoV-2 triggered a chain of public health responses that radically changed our way of living and working. Non-healthcare sectors, such as the logistics sector, play a key role in such responses. This research aims to qualitatively evaluate the non-pharmaceutical interventions (NPIs) implemented in the UK logistics sector during the COVID-19 pandemic.

Methods: We conducted nine semi-structured interviews in July-August 2020 and May-June 2021. In total 11 interviewees represented six companies occupying a range of positions in the UK's logistics sector, including takeaway food delivery, large and small goods delivery and home appliance installation, and logistics technology providers. Inductive thematic analysis was completed using NVivo12 to generate emerging themes and subthemes. Themes/subthemes relevant to interventions were mapped deductively onto an adapted Hierarchy of Control (HoC) framework, focusing on delivery workers. Themes/subthemes relevant to the process of implementation were analyzed to understand the barriers and facilitators of rapid responses.

Results: $\mathrm{HoC}$ analysis suggests the sector has implemented a wide range of risk mitigation 
medRxiv preprint doi: https://doi.org/10.1101/2022.01.28.22270013; this version posted January 29, 2022. The copyright holder for this preprint (which was not certified by peer review) is the author/funder, who has granted medRxiv a license to display the preprint in

It is made available under a CC-BY-NC-ND 4.0 International license .

Agility and Sustainability

a broad range of measures were implemented, including social distancing, internal contact tracing, communication and collaboration with other key stakeholders of the sector. Process evaluation identified facilitators of rapid responses including capacity to develop interventions internally, localized government support, overwhelming external mandates, effective communication, leadership support and financial support for self-isolation, while barriers included unclear government guidance, shortage of testing capacity and supply, high costs and diversified language and cultural backgrounds. Main sustainability issues included compliance fatigue, and the possible mental health impacts of a prolonged rapid response.

Conclusions: This research identified drivers and obstacles of rapid implementation of NPIs in response to a respiratory infection pandemic. Existing implementation process models do not consider speed to respond and the absence or lack of guidance in emergency situations such as the COVID-19. We recommend the development of a rapid response model to inform the design of effective and sustainable infection prevention and control policies and to focus future research priorities.

\section{Contributions to the field}

- $\quad$ The study offered important insights into the process of the UK logistics sector's response to the COVID-19 pandemic.

- The Hierarchy of Control (HoC) framework was adapted for the evaluation of a collection of non-pharmaceutical interventions (NPIs) implemented in a non-healthcare sector.

- Thematic analysis of qualitative data generated themes that were relevant to the process of rapid implementation of NPIs during a public health emergency.

- $\quad$ Barriers, facilitators and sustainability issues of the sector's rapid response to the COVID-19 pandemic have been highlighted to inform future research on implementation strategies.

\section{Introduction}

The novel severe acute respiratory syndrome coronavirus 2 (SARS-CoV-2) virus shocked the world in the last few days of 2019 and we still very much live in this Coronavirus disease 2019 (COVID-19) pandemic at the time of writing. In the UK, the logistics sector worked together to keep the workers and customers safe and increased capacity to cope with the sustained high level of demands. The sector employs and contracts a large number of workers to deliver a wide range products and goods to private and commercial addresses; many of them are self-employed. They could face both health and financial risks over a pandemic (1), and contribute to community transmissions (2-4). An analyses of COVID-19 mortality in England showed that, similar to other essential workers, van drivers had an increased risk of death from COVID-19, compared to non-essential workers (5). It is therefore important to introduce risk mitigation measures (RMMs) within this sector. Non-pharmaceutical interventions (NPIs) are often significant investments that require well-coordinated actions by multiple stakeholders across organizations and society $(6,7)$. To cope with imminent threats, such as a novel disease pandemic, interventions must be deployed rapidly to ensure behavioral and mindset changes occurring within a short time frame. In the case of COVID19 , mathematical models suggested that restrictive measures to reduce social mixing could reduce virus transmission and must take effect in a matter of days in order to save lives (8- 
medRxiv preprint doi: https://doi.org/10.1101/2022.01.28.22270013; this version posted January 29, 2022. The copyright holder for this preprint (which was not certified by peer review) is the author/funder, who has granted medRxiv a license to display the preprint in

It is made available under a CC-BY-NC-ND 4.0 International license .

Agility and Sustainability

81 10). While research about the health systems' response to public health emergencies has 82 provided good quality evidence $(11,12)$, similar evidence on the contribution of control

83

84

85

86

87

88 measures in non-healthcare sectors, such as the logistics sector, to control work-related transmission is so far lacking (13-15). Hence, it is imperative to learn more about what RMMs were implemented by the UK logistics companies, the barriers and facilitators of implementation and whether the control measures are sustainable in the long-term. The aim of this study was to answer these questions through interviews that explored the company representatives' opinions and experiences.

\section{Material and Methods}

We have generally followed the Consolidated Criteria for Reporting Qualitative Studies (COREQ) to report the methods and findings (16). A checklist can be found in Additional file 1 .

\subsection{Data collection}

We recruited companies through a variety of approaches, such as direct contact, approaching trade and industry associations, via personal and professional networks and a social media campaign on LinkedIn. All recruitment activities were carried out using phones, emails or online facilities. We completed nine semi-structured interviews with six companies between July and August of 2020 (Round 1) and May and June of 2021 (Round 2), with three companies interviewed twice. Each of the interviews lasted between 60 and 90 minutes. There were in total 11 participants as four companies had two or three representatives.

All participants received a study scope and Participant Information Sheet and gave verbal consent before the interviews began. We used the Zoom teleconferencing facility to audio record the interviews. Three trained postdoctoral researchers (HW, SD, CW) carried out all the interviews, with attendance by other members of the study team. Interview schedules were developed in advance, with open ended questions which included inquiries on the type of RMMs implemented, facilitators and barriers of implementation, recommendations for possible future pandemics and potential health impacts of coping with a long pandemic. The interview schedules for both round 1 and 2 are available in Additional file 2. A summary report was emailed to each participating company for comments and corrections. One company returned written comments and another discussed feedback with us over Zoom.

\subsection{Data analysis}

HW, SD and CW edited and anonymized the auto-transcripts generated by Zoom. One company supplied a detailed list of events from February 2020 to July 2020, which was also analyzed. Thematic analysis was carried out using NVivo12 software following the latent approach $(17,18)$. HW and SD studied the transcripts and events list and identified emerging themes and sub-themes, which were developed into new codes to be fitted within the codebook. . Thereafter the themes and subthemes relevant to RMMs for delivery workers were deductively matched, if appropriately, with the levels of the Hierarchy of Control (HoC) $(19,20)$. HoC ranks preventative measures according to their expected level of protectiveness against one particular hazard, moving from the most protective measures that eliminate the hazard completely from the work environment, down to personal protective equipment (PPE), the last layer of protection for workers (see Figure 1). The mapping exercise was reviewed and discussed extensively within the team and with experts from the Health and Safety Executive (HSE) and Public Health England (PHE, now known as UK Health Security 
medRxiv preprint doi: https://doi.org/10.1101/2022.01.28.22270013; this version posted January 29, 2022. The copyright holder for this preprint (which was not certified by peer review) is the author/funder, who has granted medRxiv a license to display the preprint in It is made available under a CC-BY-NC-ND 4.0 International license .

Agility and Sustainability

Agency). Codebooks were developed separately for the two rounds of interviews to allow for changes that occurred over the course of the pandemic. Based on the agreed codebooks, HW and SD then coded the transcripts independently, with coding results merged to assess intercoder reliability. The percentage of agreement between the two coders was very high $(>90 \%)$ and the average Kappa coefficient was 0.61 for the first round and 0.51 for the second round ( $0.41-0.75$ is considered fair to good (21)). Individual codes that showed higher discrepancy were discussed and consensus was reached.

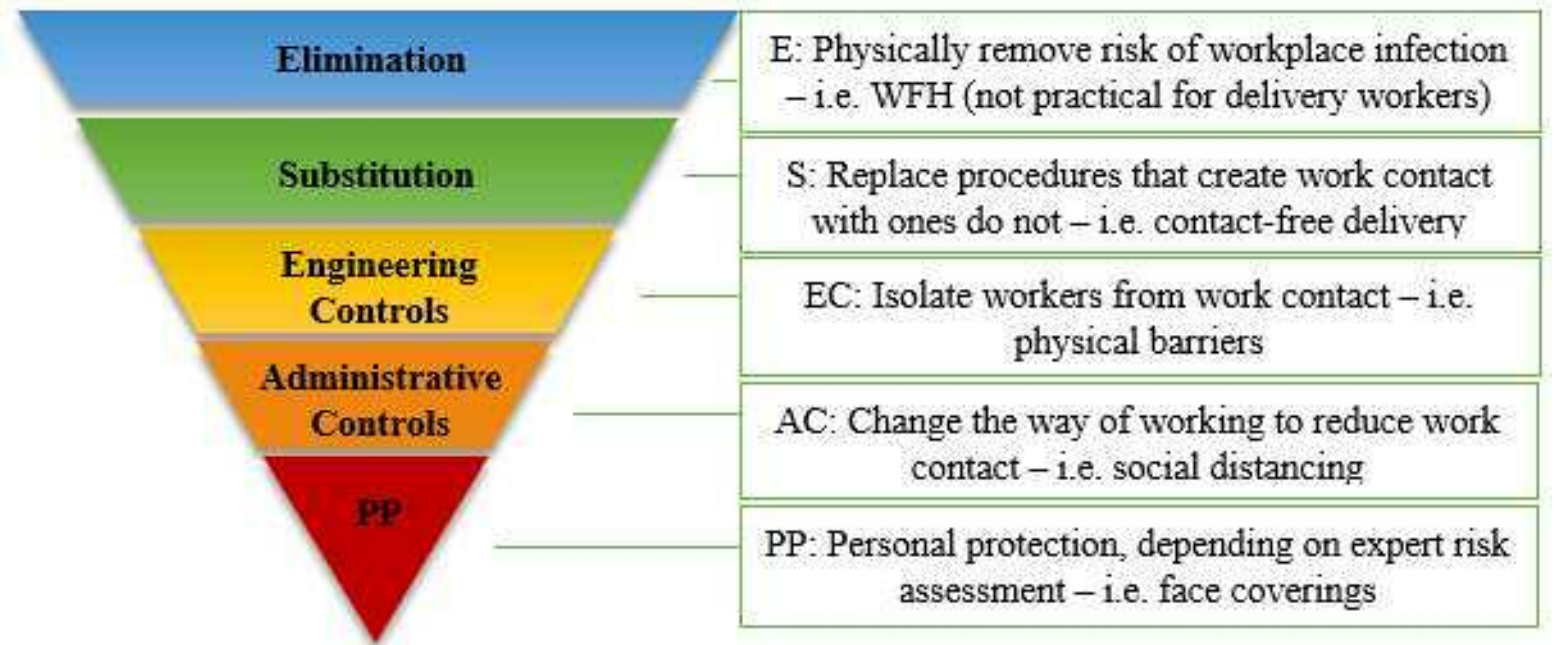

Abbreviation: WFH: Working from home; EC: Engineering control; AC: Administrative control; PP: Personal protection

Figure 1 HoC: COVID-19 - Delivery workers (adapted from HSE websitesi)

The HoC analysis focused on the delivery workers who would collect deliveries from a workplace (i.e. warehouses or depots) and deliver them to customer premises, using a certain type of vehicle. For large items, they might also enter customer premises in order to drop the deliveries to a designated room (Room of Choice) or to complete the installation.

\section{$3 \quad$ Results}

\subsection{Characteristics of participating companies}

Participants represented one takeaway food delivery platform, four logistics companies that delivered large and small items and one technology provider for food and grocery chain stores i.e. supermarkets and restaurant chains. Most of the representatives that we recruited were directly involved in the day-to-day running of the logistics business. However, for grocery store deliveries, we only managed to recruit a technology developer that served the food and grocery chains. All the delivery companies were large employers $(500+)$ except the technology developer. The roles of the participants covered a range of functions in the companies, including health and safety, operation, operational support, communication, marketing and external affairs. Delivery of large items was normally fulfilled by two-person teams, while parcel and takeaway food deliveries were fulfilled by lone drivers or bicycle riders. Of the five delivery companies, delivery workers were engaged as self-employed in four, with one large items delivery company employing drivers directly.

\subsection{Interventions -- HoC analysis}


medRxiv preprint doi: https://doi.org/10.1101/2022.01.28.22270013; this version posted January 29, 2022. The copyright holder for this preprint (which was not certified by peer review) is the author/funder, who has granted medRxiv a license to display the preprint in

It is made available under a CC-BY-NC-ND 4.0 International license .

Agility and Sustainability

153 HoC analysis focuses on the interventions. A wide range of RMMs were designed and

154 implemented by the interviewed companies. Through the pandemic, they continued to do so to tackle newer challenges, such as the emergence of new variants, risks of increased transmission during the winter season, and adapting to new government measures, such as mass testing and vaccination. $\mathrm{HoC}$ analysis excluded the technology provider as they were not directly involved in delivery work. We summarized the RMMs that were discussed in the interviews in Table 1. Food 1 refers to the takeaway platform, Parcel 1 and 2 refer to the two parcel delivery companies, and Large 1 and 2 refer to the two large items delivery companies. Food 1 engages couriers using an app and does not operate any physical sites, while the other four companies do, of which, Large 1 and 2 also provide company vehicles.

Table 1 HoC analysis - COVID-19 RMMs implemented by the logistics companies for delivery workers

165 (Table 1 is presented at the end of the manuscript)

No measures taken by the companies fell within the definition of Elimination. For example, working from home (WFH) would eliminate risk of infection from workplaces but is not practical for delivery workers. "Other staff (i.e. office workers) WFH" is treated as an administrative control (AC) measure as it would help reduce workplace contacts for delivery 170 workers.

Contact-free delivery was considered a Substitution measure and the most practical in the context of home deliveries. All five companies named it as the most important measure to reduce contacts for delivery workers and introduced it from a very early stage of the pandemic. It was achieved by drivers doing doorstep drop-off with no signature required. Proof of delivery that previously required customers to sign a paper document or the handheld unit with a pen, a finger or a wand was replaced by taking a photo at the doorstep or signed by the driver's colleague when it was two-person deliveries.

"The moment the UK went into lockdown and we moved to doorstep delivery only." [Large 1]

"As soon as lockdown was announced... we stopped (delivery to) room of choice as well." [Large 2]

"So quite quickly we had to establish a way of how could we achieve that without actually getting someone to touch our equipment or interact with the driver... And the way we achieved it is we took a photograph... It was accepted very quickly that that was the new form of signature." [Parcel 1]

"As well as asking drivers to knock on the door and then step back, we've also stopped getting signatures.” [Parcel 2]

"We rolled out contact-free delivery across our entire network... so everybody was doing contract free delivery. " [Food 1]

189 In terms of engineering controls (EC) measures, four of the companies that operated physical sites had installed physical barriers, changed workplace layout and restricted or suspended some services. One of them reported they erected temporary facilities such as portaloos and resting areas for visitors and third-party drivers. Companies took different measures to minimize contact for two-person deliveries. For example, Large 2 hired additional cars for the second delivery personnel so that the two-person team did not need to share the vehicle. 
medRxiv preprint doi: https://doi.org/10.1101/2022.01.28.22270013; this version posted January 29, 2022. The copyright holder for this preprint (which was not certified by peer review) is the author/funder, who has granted medRxiv a license to display the preprint in

It is made available under a CC-BY-NC-ND 4.0 International license .

Agility and Sustainability

195 They stopped the measure following publication of government guidance on sharing vehicles

196 at work in June 2020. Large 1 suspended installation service immediately following the first

197 lockdown and resumed it when the government guidance about working in customers' homes

198 was introduced and they were able to establish safe work practice.

199 Most control measures reported were at the AC level. All five companies reported

200 implementing self-isolation (if symptomatic, tested positive or close contact), hygiene

201 measures, Information Instruction \& Training (IIT), working with industry and authorities

202 and compliance \& data monitoring. Measures relevant to IIT or communication were

203 described the most frequently by the participants. All participants discussed how they

204

205

206

207

208

209

210

communicated the guidance, instructions and the changes to their employed or self-employed drivers, employees and customers throughout the period. These included daily or weekly bulletins, virtual Town Hall meetings, emails, phone texts, messaging platforms such as Yammer, YouTube channels, face-to-face briefings (if workspace allowed social distancing) and educational phone calls when issues arose. They monitored COVID compliance by collecting information via staff surveys, customer feedback, observational monitoring by dedicated staff or CCTV and site audits. All of them reported thorough promotion of hand wash and enhanced cleaning routines.

212 All four companies that operated from distribution centers implemented pairs and bubbles,

213 social distancing, workplace contact tracing and workplace infection monitoring. Pairing refers to fixing each two-person delivery team permanently. Before the pandemic these pairs would change every day or in some cases multiple times per day. Drivers and warehouse staff would be grouped by location to establish working group bubbles, with no rotation between sites. The key was to keep the same teams together as much as possible to reduce the number of contacts, and to make workplace contact tracing more effective. When a case was confirmed, the workers who had been in close contact with the infected individual would be notified immediately to go into self-isolation. The other AC measures reported included staggered working where breaks and beginning of shifts were staggered at intervals, i.e. 15 minutes to minimize contact. All of the interviewed companies demonstrated a strong capacity in workplace infection rate monitoring, especially in the second round of interviews. Four of them stated infection rates in the workforce merely reflected community infection rates, indicating limited workplace transmission. One reported they had outbreaks within workplaces when the Alpha variant emerged in winter 2020. They then immediately deployed third-party testing facilities to test the entire workforce at those sites.

228 For personal protection and personal hygiene, participants reported they provided drivers with face coverings, gloves and hand sanitizers.

\section{$230 \quad 3.3 \quad$ Implementation - process evaluation}

In this section, we investigate the process of implementation and identify barriers, facilitators and issues that might affect sustainability. The process had prominent features, such as the speed to action, the overwhelming external pressure, improvised interventions, ad hoc approach, a fast-evolving situation and steep learning curves for all stakeholders. Based on the emerging themes of our thematic analysis, we summarized 15 key characteristics of rapid responses that can be categorized into five domains, with relevant barriers and facilitators identified in Table 2. 
medRxiv preprint doi: https://doi.org/10.1101/2022.01.28.22270013; this version posted January 29, 2022. The copyright holder for this preprint (which was not certified by peer review) is the author/funder, who has granted medRxiv a license to display the preprint in

It is made available under a CC-BY-NC-ND 4.0 International license .

Agility and Sustainability

240 (Table 2 is presented at the end of the manuscript)

\subsubsection{Intervention characteristics}

243 The themes that emerged in relation to interventions characteristics included source of 244 interventions, strength \& quality of evidence and costs.

245 The companies developed the interventions drawing from both external and internal sources.

246 External sources were mostly government guidance such as social distancing, face covering and hand washing, which were relatively standardized. For companies that operate in multiple countries, signals from other countries also provided sources of intervention. For example, Parcel 1 mentioned they had secured a supply of facemasks (described as threelayer paper masks) for their UK workers, as colleagues from across the world recommended this as a preventative measure at the early stages of the pandemic. Internally developed measures generally followed the principal of minimizing contact but with customized characteristics. Contact-free delivery is an example of an internally developed intervention with slightly different features designed by each company. Both Parcel 1 and 2 used photographs to replace customer signatures, while Large 1 required no signature and Large 2 asked the driver's "mate" (the other personnel in a two-person delivery team) to sign as a proof of delivery. Food 1 required no signature and strongly advised online payment. When cash payment was necessary, they then asked the money to be put into an envelope.

Barrier 1 Barriers to rapid development of interventions here appeared to be the lack of and changing government guidance.

Facilitator 1 The resourcefulness and capacity to design and develop interventions internally appeared to be a facilitator.

The companies reported how they actively collected data to monitor the effectiveness of communication and infection rates. They mentioned customer and staff surveys, monitoring message click rate and dwelling time, and monitoring infection and self-isolation rates. Participants appeared to be more confident about the quality and validity of the evidence in round 2 . During round 1, they generally reported a very low number of confirmed cases, while during round 2, participants provided more details about how they collected and analyzed data systematically. They were able to make clear statements about the perceived cause of the outbreaks. For example, Large 1 discussed how the Alpha variant, combined with lack of ventilation in the winter season, had a significant impact on transmission in the workplace. They were clear about timing, location and job roles that were the most affected. Parcel 2 showed to us over Zoom their COVID infection dashboard where data were systematically collected, analyzed and displayed for decision making.

Barrier 2 Limited testing capacity and shortage of supply at the beginning of the pandemic appeared to be major barriers. This capacity was visibly improved during the course of the pandemic as demonstrated by the round 2 interviews.

Barrier 3 NPIs implemented at speed appeared to be costly. The participants talked about direct and associated costs including investment, supply or equipment and the knock-on effect on efficiency. Interventions such as deploying more vehicles, providing equipment and furniture to allow office staff to WFH, and providing hand sanitizers and face coverings would obviously add to costs. Financial support, such as 14-day COVID sick leave pay for 
medRxiv preprint doi: https://doi.org/10.1101/2022.01.28.22270013; this version posted January 29, 2022. The copyright holder for this preprint (which was not certified by peer review) is the author/funder, who has granted medRxiv a license to display the preprint in

It is made available under a CC-BY-NC-ND 4.0 International license .

Agility and Sustainability

283 the self-employed and additional bonuses, were direct costs. There was also other investment such as communication systems, posters and markings, sanitary stations, physical barriers and alteration of workplaces. One participant mentioned that costs related to COVID-19 RMMs were in the range of hundreds of thousands of pounds every month at that time. However, participants were also in universal agreement that the companies had been performing well since the first lockdown as demand increased and sustained at high level, which might have helped to absorb the costs.

\subsubsection{External environment}

Three themes emerged in relation to external environment, including prioritization of COVID safety, unprecedented collaboration within the industry and overwhelming external mandates to enact rapid responses.

294 The UK government imposed lockdown measures in March and November 2020 and January 2021 to stop non-essential contact and travel. Nevertheless, delivery of food and other essential supplies was recognized as essential work by the government. Hence worker and customer safety must be prioritized and the companies modified work procedures to reduce work contact, including suspension of services, such as installation or Room of Choice, and stopped procedures, such as signing on documents or equipment.

300 The level of collaboration within the industry was unprecedentedly high as reported by the

301 participants. It included working with the sector including competitors, the government and international collaboration within the organizations.

303 Facilitator 2 Localized government support was a facilitator of the rapid response.

304 Participants described working with the local police, Department for Environment, Food and Rural Affairs (DEFRA), HSE, PHE, National Health Service (NHS) and local authorities. When there was a high level of uncertainty, the companies appreciated the support from local authorities and local branches of HSE, PHE and unions. They would send their internal guidance and risk assessment to these bodies and obtain their opinions. The support was personalised to the companies, which then provided the companies with confidence to implement these measures.

311 Networking in this sector was strengthened especially at the beginning of the pandemic.

312 Participants spoke highly about the industry forum organised by DEFRA that occurred 313 weekly and then bi-weekly. It was unprecedented as all the main competitors of the industry 314 joined. Participants reported that they shared best practices with an open mind and worked 315 together to contribute to the development of government guidance. Email groups were set up 316 to facilitate exchange of ideas and questions.

317 Facilitator 3 In addition to the networked collaborative activities, the numerous government 318 recommendations, guidelines and updates, and that COVID-19 dominated the media and the Internet for a substantial period of time, all created an overwhelming incentive for the companies to respond rapidly.

\subsubsection{Organizational setting}

322 Four themes emerged in this domain, including effective communications, safety culture,

323 facilitating implementation climate and leadership commitment for implementation. 
medRxiv preprint doi: https://doi.org/10.1101/2022.01.28.22270013; this version posted January 29, 2022. The copyright holder for this preprint (which was not certified by peer review) is the author/funder, who has granted medRxiv a license to display the preprint in

It is made available under a CC-BY-NC-ND 4.0 International license .

Agility and Sustainability

324 Facilitator 4 Effective communications were emphasized by many participants as an

325 important facilitator of rapid responses. They reported that communications were highly valued by the staff because the situation had been a fast-evolving one. Uncertainties and lack of specific guidance meant that workers needed that information to guide their everyday work. Every time new threats, guidance or public measures came out, such as regional lockdowns, new variants, mass testing or the vaccination program, it was important the company communicated guidance and recommendations that were specific to their work context.

332 Barrier 4 A number of participants reported that language and the complexity of the guidance could be a challenge as English is the second language for many workers within this sector. To tackle this issue, they simplified the language and added infographics to illustrate the meaning. A couple of participants mentioned the cultural background of the workforce could be a barrier to enforce social distancing as certain cultures tend to socialise more and workers of that background were likely to share transport to work or accommodations. This however could also be a facilitator in some circumstances as Large 1 explained how they paired "sons and dads, mums and dads" or drivers from the same households or family

COVID-19 safety was discussed by the participants as a belief rather than something they reluctantly comply to. One participant articulated it particularly well.

"We have a culture in our leadership of putting safety first... we track our [COVID-19] numbers in [Large 2] but there's no incentive. You know I'm not bonused, my performance isn't measured on whether I achieve safety or not. We all do it because it's the right thing to do." [Large 2]

347 The organizational climate for implementing interventions played a facilitating role. Key stakeholders felt the necessity to change in order to keep safe and contain the spread of the virus, as one of the participants described:

350 "The behaviour change, the couriers, the restaurants, the customers was helped by the fact that every single aspect of life has changed. So people [were] kind of shocked into it." [Food 1]

353 Facilitator 5 Three of the companies mentioned they provided financial support such as sick leave pay to support the self-employed drivers to take COVID-related self-isolation. It can facilitate adherence among delivery workers as many of them were self-employed and did not enjoy statutory sick pay. They also mentioned that they promoted intangible incentives such as customers' appreciation messages and exemplar stories to be put on their websites and communication channels.

Facilitator 6 Key stakeholders' commitment for implementation appeared high. Leadership engagement was evident in all the interviews. Two participants particularly emphasized the influence from the leadership team that keeping workers safe from COVID-19 infection was the right thing to do and would reward the business in the long-term. This is then linked to resources dedicated for implementation. It appeared that the companies allocated adequate resources timely to support the interventions. 
medRxiv preprint doi: https://doi.org/10.1101/2022.01.28.22270013; this version posted January 29, 2022. The copyright holder for this preprint (which was not certified by peer review) is the author/funder, who has granted medRxiv a license to display the preprint in

It is made available under a CC-BY-NC-ND 4.0 International license.

Agility and Sustainability

365

366

367

368

369

370

371

372

373

374

375

376

377

378

379

380

381

382

383

384

385

386

387

388

389

390

391

392

393

394

395

396

397

398

399

400

401

402

403

\subsubsection{Implementation process}

The implementation process can be characterized as an unplanned rapid response, full engagement, strong execution and continuous reflecting $\&$ evaluating.

"Rapid response" was a prominent feature emphasized by all of the participants. From early March 2020, the volume of home deliveries "went through the roof". Participants mentioned figures such as:

“Our sales spiked... 202\% year on year compared to previous March” [Large 1]

"Volume of orders have gone up, way up, absolutely unbelievable" [Logistics technology provider]

In response, the sector moved rapidly to increase the capacity, while ensuring worker and customer safety. Changes and interventions were obviously not planned in advance. Supply chain networks are underpinned by technology that help streamline the service. The technology provider participant described the chaos experienced by food and grocery chains during the first lockdown. Restaurants, cafes and small retailers were closed and hence the volume of that part of the supply chain went down to zero whilst supermarkets suddenly faced much higher demands which caused blockages and bottlenecks in their network. "It completely destroyed that (food) supply chain", the participant recalled. Nevertheless, their engineers rose to the challenge and developed solutions for the clients in just six days. The participant told us internally the grocery chains called it "the second Christmas" as they "turned on the Christmas protocols for everything" in a matter of days, whereas normally preparations for the Christmas peak would take a few months.

Other participants also passionately described the speed of implementation.

"We were able to react really quickly. And we were able to get, as I've said, sort of, PPE, standards, working from home, all of those things in really, really quickly. We even surprised ourselves... we really pride ourselves on how quickly... and we've done it really smoothly." [Parcel 1]

"And so lots and lots of shared facilities across all of our sites that we just had to change pretty much overnight and because we didn't stop operate so real big challenges. " [Large 2]

There were many more examples that described deployment of interventions in a very short timeframe such as overnight, within a week, or in just a few days.

As an unplanned response, continuous risk assessment combined with an experimental approach were essential. There were measures that were considered but not adopted or were on hold for future review. This can be an important feature for learning when facing emergencies caused by novel threats in the future. Participants discussed these measures and reasons for not adopting them.

"We explored offering our people tests, we decided not to do that because there was a lot of uncertainty. This was around May [2020] time. There was a lot of uncertainty about which test, availability of tests... We wrestled with the ethics of if we take a big batch of tests. Does that take away from the NHS and care homes?" [Large 1] 
medRxiv preprint doi: https://doi.org/10.1101/2022.01.28.22270013; this version posted January 29, 2022. The copyright holder for this preprint (which was not certified by peer review) is the author/funder, who has granted medRxiv a license to display the preprint in

It is made available under a CC-BY-NC-ND 4.0 International license.

Agility and Sustainability

"The key reason we didn't do that [ordering facemasks in bulks] immediately was because we wanted to ensure that what we were ordering wouldn't impact the NHS and care homes receiving it." [Food 1]

When mass testing became available later in the pandemic, it was not immediately adopted by the companies. Participants reasoned that regular lateral flow device testing could not be easily integrated into their daily operations. One participant expressed a strong view regarding the possible effect of workplace testing in undermining other existing measures.

"Workplace testing when you're dealing with certain members of society actually has a detrimental effect in terms of following COVID secure guidelines that we've put in place. So what we felt was that by introducing workplace testing people felt that was a level of security that I didn't agree with, and that if they felt that they tested negative, then they didn't need to follow social distancing wear face coverings so.... my view is quite strong on this is that actually lateral flow testing undermines a lot of the measures that we really need people to be focusing on." [Parcel 2]

\subsubsection{Sustainability}

A rapid response mode may be effective in the short-term but can run into problems if it lasted longer than expected and hence introduce questions about sustainability.

As the pandemic continued into 2021, some workers developed compliance fatigue and this became a barrier to effective implementation. In round 2 interviews, we asked the participants whether they observed any relaxed attitudes towards the COVID measures. Participants agreed that to some extent attitudes had relaxed and described how they took actions to mitigate this. They highlighted the need to maintain effective communications by providing a "permanent alert" or "constant reminder" to workers. Two participants mentioned they added extra monitoring, that is, sending out staff to walk around the workplaces and giving colleagues a reminder whenever they observed behaviours not meeting the standard.

In round 2, all participants stated that high volume of home deliveries continued even when lockdown was lifted. They told us that the industry was used to working on full speed during the Christmas peak that was normally from late October to the end of December. As mentioned earlier, the industry immediately switched on the Christmas protocol from March 2020 and this continued into 2021. Mental health impacts of sustained high workload were mentioned by many of the participants. Participants expressed concerns about overwork, burnout and presenteeism.

"I've got a massive concern about burnout, about mental health, and you know the issues that overwork create... the level of additional work has just continued... it's not just the burnout because you can bring the extra people in, it's the prolonged on and on and on and on and no light at the end of the tunnel." [Parcel 1]

For office workers, while some appreciated the time saved from commuting by WFH, not all have an appropriate work environment in their homes and some reported feeling isolated. Participants also mentioned that the companies were surveying workers regarding to their mental wellbeing and trying to offer some support.

We have provided a schematic diagram to illustrate the important findings in Figure 2. It highlights the key characteristics of rapid responses, grouped into five domains (interventions 
medRxiv preprint doi: https://doi.org/10.1101/2022.01.28.22270013; this version posted January 29, 2022. The copyright holder for this preprint (which was not certified by peer review) is the author/funder, who has granted medRxiv a license to display the preprint in It is made available under a CC-BY-NC-ND 4.0 International license .

Agility and Sustainability

446 characteristics, external environment, organizational setting, and sustainability), with the implemented NPIs matched with HoC at the center.

External environment

Prioritisation of safety

Unprecedented collaboration within the industry Overwhelming external and policy mandates

Organizational setting

Effective communications

Safety culture

Facilitating implementation climate

Leadership commitment for implementation

Intervention

characteristics

Source of interventions:

External and

internal

Quality of

evidence:

Developed

capacity

Costs:

Absorbing costs

\section{NPIs}

E: not practical

S: contact-free delivery

EC: physical barriers, ventilation etc. AC: IIT, social distancing, minimising contact, monitoring etc. PP: face coverings

\section{Implementation process Rapid response, full engagement, strong execution and continuous reflecting \& evaluating}

Sustainability

(long-term effects)

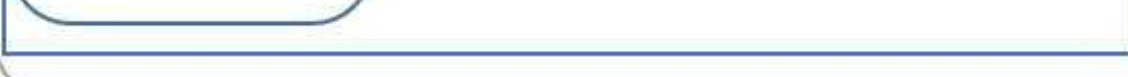

Figure 2 Qualitative evaluation of non-pharmaceutical interventions in nonhealthcare sector: an example of the UK logistics sector during COVID-19 pandemic

\section{Discussion}

This empirical research is responding to the call for knowledge and recommendations for preventive interventions to reduce the transmission of SARS-CoV-2. It offered a case analysis for the UK logistics sector, with an occupational focus on delivery workers.

The process of implementation had prominent features, such as the speed to action, the overwhelming external pressure, improvised interventions, and steep learning curves for all stakeholders. We scoped the literature to identify an appropriate theoretical model to inform the analysis. Multiple existing frameworks offered some useful insights, including the REAIM (Reach, Efficacy, Adoption, Implementation and Maintenance) (22, 23), CFIR (Consolidated Framework for Implementation Research) (24, 25), PRECEDE-PROCEED $(26,27)$ and other process evaluation models that generally included components such as recruitment, dose delivered, dose received, fidelity, satisfaction, maintenance and context (28). However, they generally assumed a systematically developed intervention program 
medRxiv preprint doi: https://doi.org/10.1101/2022.01.28.22270013; this version posted January 29, 2022. The copyright holder for this preprint (which was not certified by peer review) is the author/funder, who has granted medRxiv a license to display the preprint in

It is made available under a CC-BY-NC-ND 4.0 International license .

Agility and Sustainability

465 implemented with some extent of control, and none of them fully captured the characteristics

466 of this sector's response to COVID-19. It suggests the urgency of developing a rapid

467 response model that can first, analyze a collection of NPIs implemented in occupational settings. When responding to a pandemic, NPIs are likely to be implemented simultaneously with many other measures and a single measure would not be sufficient (20). Second, the model should take into account the barriers and facilitators of rapid responses to a public health emergency (29).

472 In addition to the well-known COVID-19 NPIs, such as face coverings, hand washing and social distancing (14), our HoC analysis identified measures that were important to the delivery work setting, including contact-free delivery, fixed pairing, effective communications/IIT and sectoral collaboration. Contact-free delivery and fixed pairing (for two-person deliveries) were new measures improvised by this sector during this COVID-19 pandemic and became established practices as the participants told us. Working collaboratively with key stakeholders of the sector, including the competitors and local and state authorities was considered an important measure and a facilitator in outer setting (25).

We identified important barriers and facilitators to rapid responses. Financial support for selfisolation was considered a facilitator for delivery workers especially the self-employed, as a previous study found sick leave pay was associated with adherence to infection, prevention and control measures among healthcare workers (30). In addition, COVID-19 infection rates among delivery and warehousing workers from the developed and developing countries varied significantly. For example, in Canada, it was as low as $0 \%(31)$, whilst in Ecuador it was $15.2 \%$ (32). Although the sample of the two studies may not be directly comparable, it is possible that financial conditions served a social determinant of COVID-19 related health outcome (33). The sector's capacity to design and develop interventions internally was also a key facilitator. As SARS-CoV-2 was a novel virus and the pandemic was fast-evolving, a response protocol or prevention guidance for the logistics sector was not available in the UK initially. Hence, internal knowledge and assessment was an important source of intervention development. Companies also used their judgement to decide not to adopt certain measures, such as workplace testing. This echoes the concern that people without COVID-19 selfisolating due to false-positive lateral flow test results could be a cost to the individual, their household, and their workplace (34). In addition, localized government support, effective communication and leadership support were considered facilitators. This is in line with findings from existing studies that evaluated the implementation of interventions programs $(35,36)$. Overwhelming external mandates was probably a prominent facilitator associated with the situation of a pandemic as few other health interventions received media attention like those for COVID-19.

Major barriers included unclear and changing government guidance, lack of testing capacity, shortage of facemasks, and diversified language and cultural backgrounds. Barriers associated with government guidance, testing capacity and supply of PPE mainly affected the rapid response at the early stages $(37,38)$. Language and cultural barriers were also identified by multiple intervention studies previously $(36,39)$. Carefully designed trainings were recommended, which were consistent with the measure took by the companies we interviewed. We identified compliance fatigue in the second interview round. Such behavioral changes reflected a response to adjustments in individuals' risk assessment (40, 41), especially when the government announced their Roadmap to lift restrictions. Our 510 participants suggested adding more behavior monitoring measures and reminders to maintain 511 the level of alert. Participants mentioned the high costs associated with these NPIs but also 
medRxiv preprint doi: https://doi.org/10.1101/2022.01.28.22270013; this version posted January 29, 2022. The copyright holder for this preprint (which was not certified by peer review) is the author/funder, who has granted medRxiv a license to display the preprint in

It is made available under a CC-BY-NC-ND 4.0 International license .

Agility and Sustainability

512 believed such costs were compensated by increased volume. Going forward, a more

513 systematic approach should evaluate such costs from health economics perspective.

514 The prolonged WFH measure and sustained high workload both add to work stress (42). It

515 highlighted a key sustainability issue associated with the current approach to dealing with the

516 pandemic. The concern is consistent with findings from studies that examined healthcare staff

517 burnout during COVID-19 (43-45). It is not sustainable, and a more systematic approach and

518 coherent sectoral strategy is urgently needed.

519 This paper is based on views expressed by those in managerial roles rather than the delivery

520 drivers. We recognize that their views could differ significantly from the frontline workers'

521 perspective. For example, surveys among app-based drivers reported concerns of infection

522 risks from interactions with the public and insufficient workplace protections such as access

523 to personal protective equipment (PPE) $(31,46)$. Delivery workers in the French gig

524 economy also expressed concerns of financial precarity and lack of union support (1).

525 Another potential limitation of this study is the small sample size and the size of the participated companies. The sector was extremely busy throughout the pandemic and our invitations were declined by the majority of companies we approached. We were not able to directly assess the effectiveness of the interventions, but the perceived effectiveness of the participants.

\section{Conclusion}

531 This qualitative study provides a rich source of contextualized data to evaluate rapid 532 implementation of COVID-19 NPIs in the UK logistics sector. We assessed the interventions against an occupational health and safety standard and identified barriers, facilitators and sustainability issues in the process of a rapid response. In conclusion, the UK's logistics sector rose to the challenge and rapidly developed and implemented a wide range of RMMs in a fast-evolving pandemic. They closely followed national and local guidelines available to them at the time and developed RMMs resourcefully when guidelines were lacking. Elimination of the risk was not practical for the delivery workers and most control measures were considered administrative controls. Contact-free delivery was commonly implemented and considered effective. Participants were confident that the RMMs played an important role in reducing workplace transmission risk for delivery workers. Further research is now needed to design and evaluate models and tools to apply sustainable respiratory infection prevention and control measures across work settings, as well as taking into account the more vulnerable work and social groups.

\section{Ethics statement}

546 The project was reviewed and approved by the University Research Ethics Committee at 547 University of Manchester, Ref: 2020-9787-15953. Consent to participation was verbally

548 obtained before the commencement of the interviews.

\section{$7 \quad$ Data availability statement}

550 The datasets generated for this study are available on request to the corresponding author. 
medRxiv preprint doi: https://doi.org/10.1101/2022.01.28.22270013; this version posted January 29, 2022. The copyright holder for this preprint (which was not certified by peer review) is the author/funder, who has granted medRxiv a license to display the preprint in It is made available under a CC-BY-NC-ND 4.0 International license .

Agility and Sustainability

552 The authors declare that the research was conducted in the absence of any commercial or

553 financial relationships that could be construed as a potential conflict of interest.

\section{Author Contributions}

555 Interview schedules and codebooks were developed by HW, SD, CW and MvT with

556 extensive inputs from the rest of the team and collaborators at HSE and PHE. HW, SD and

$557 \mathrm{CW}$ carried out the interviews and completed the analysis. HW and SD drafted the paper.

$558 \mathrm{MvT}, \mathrm{YH}, \mathrm{DD}, \mathrm{IH}, \mathrm{MR}$ and AV commented and edited each version of the manuscript. All

559 the authors reviewed and approved the final version.

\section{$560 \quad 10 \quad$ Funding}

561 This project was funded by the UK Research and Innovation (UKRI) and National Institute

562 for Health Research (NIHR) COVID-19 Rapid Response call, Grant Ref: MC_PC_19083.

$563 \mathrm{MvT}$ is the Principal Investigator of the project.

\section{Acknowledgments}

565 The authors would like to thank the project's advisory group that consist of Catherine

566 Noakes, Chris Armitage, Sheena Johnson, Jeanette Edwards, Barbara Hockey, Nina Day,

567 Nick Gent and Thomas House, for their advice that helped refine the aims and objectives of

568 this article. We would also like to thank Helen Beers and Peter Baldwin from HSE for their

569 advice on the business engagement, thematic analysis and feedback to companies.

\section{References}

1. Apouey B, Roulet A, Solal I, Stabile M. Gig Workers During the Covid-19 Crisis in France: Financial Precarity and Mental Well-Being. Journal of Urban Health (2020). doi: 10.1007/s11524-020-00480-4.

575 2. Bernardes-Souza B, Júnior SRC, Santos CA, Neto RMDN, Bottega FDC, Godoy DC, et al. Logistics Workers Are a Key Factor for Sars-Cov-2 Spread in Brazilian Small Towns: Case-Control Study. JMIR Public Health Surveill (2021) 7(9):e30406. Epub 1.9.2021. doi: $578 \quad 10.2196 / 30406$.

$5793 . \quad H u a n g$ H. Riders on the Storm: Amplified Platform Precarity and the Impact of 580 Covid-19 on Online Food-Delivery Drivers in China. Journal of Contemporary China 581 (2021):1-15. doi: 10.1080/10670564.2021.1966895.

582 4. Lan F-Y, Wei C-F, Hsu Y-T, Christiani DC, Kales SN. Work-Related Covid-19

583 Transmission in Six Asian Countries/Areas: A Follow-up Study. PLOS ONE (2020)

584 15(5):e0233588. doi: 10.1371/journal.pone.0233588.

585 5. Nafilyan V, Pawelek P, Ayoubkhani D, Rhodes S, Pembrey L, Matz M, et al.

586 Occupation and Covid-19 Mortality in England: A National Linked Data Study of 14.3

587 Million Adults. Occupational \& Environmental Medicine (2021) In press. doi:

$588 \quad 10.1101 / 2021.05 .12 .21257123$.

589 6. Faija CL, Gellatly J, Barkham M, Lovell K, Rushton K, Welsh C, et al. Enhancing the 590 Behaviour Change Wheel with Synthesis, Stakeholder Involvement and Decision-Making: A 591 Case Example Using the 'Enhancing the Quality of Psychological Interventions Delivered by 
medRxiv preprint doi: https://doi.org/10.1101/2022.01.28.22270013; this version posted January 29, 2022. The copyright holder for this preprint (which was not certified by peer review) is the author/funder, who has granted medRxiv a license to display the preprint in It is made available under a CC-BY-NC-ND 4.0 International license .

Agility and Sustainability

592 Telephone' (Equity) Research Programme. Implementation Science (2021) 16(1):53. doi:

593 10.1186/s13012-021-01122-2.

$5947 . \quad$ Roussy V, Riley T, Livingstone C. Together Stronger: Boundary Work within an

595 Australian Systems-Based Prevention Initiative. Health Promot Int (2020) 35(4):671-81.

596 Epub 2019/07/02. doi: 10.1093/heapro/daz065.

5978 8. Prem K, Liu Y, Russell TW, Kucharski AJ, Eggo RM, Davies N, et al. The Effect of

598 Control Strategies to Reduce Social Mixing on Outcomes of the Covid-19 Epidemic in

599 Wuhan, China: A Modelling Study. The Lancet Public Health. doi: 10.1016/S2468-

600 2667(20)30073-6.

601 9. Ferguson NM, Laydon D, Nedjati-Gilani G, Imai N, Kylie Ainslie, Marc Baguelin, et 602 al. Impact of Non-Pharmaceutical Interventions (Npis) to Reduce Covid-19 Mortality and 603 Healthcare Demand. London: Imperial College London, (2020) Contract No.: Report 9.

604 10. Flaxman S, Mishra S, Gandy A, Unwin HJT, Mellan TA, Coupland H, et al.

605 Estimating the Effects of Non-Pharmaceutical Interventions on Covid-19 in Europe. Nature 606 (2020) 584(7820):257-61. doi: 10.1038/s41586-020-2405-7.

607 11. Reece S, Brown CS, Dunning J, Chand MA, Zambon MC, Jacobs M. The Uk's

608 Multidisciplinary Response to an Ebola Epidemic. Clin Med (Lond) (2017) 17(4):332-7. doi:

609 10.7861/clinmedicine.17-4-332.

610 12. Zumla A, Dar O, Kock R, Muturi M, Ntoumi F, Kaleebu P, et al. Taking Forward a

611 'One Health' Approach for Turning the Tide against the Middle East Respiratory Syndrome

612 Coronavirus and Other Zoonotic Pathogens with Epidemic Potential. International Journal of

613 Infectious Diseases (2016) 47:5-9. doi: https://doi.org/10.1016/j.ijid.2016.06.012.

614 13. Milat AJ, Bauman A, Redman S. Narrative Review of Models and Success Factors for

615 Scaling up Public Health Interventions. Implementation Science (2015) 10(1):113. doi:

616 10.1186/s13012-015-0301-6.

617 14. Talic S, Shah S, Wild H, Gasevic D, Maharaj A, Ademi Z, et al. Effectiveness of 618 Public Health Measures in Reducing the Incidence of Covid-19, Sars-Cov-2 Transmission, 619 and Covid-19 Mortality: Systematic Review and Meta-Analysis. BMJ (2021) 375:e668302. 620 doi: 10.1136/bmj-2021-068302.

621 15. Breuer E, Lee L, De Silva M, Lund C. Using Theory of Change to Design and 622 Evaluate Public Health Interventions: A Systematic Review. Implementation Science (2016) 623 11(1):63. doi: 10.1186/s13012-016-0422-6.

624 16. Tong A, Sainsbury P, Craig J. Consolidated Criteria for Reporting Qualitative 625 Research (Coreq): A 32-Item Checklist for Interviews and Focus Groups. International 626 Journal for Quality in Health Care (2007) 19(6):349-57. doi: 10.1093/intqhe/mzm042.

627 17. Braun V, Clarke V. Using Thematic Analysis in Psychology. Qualitative research in 628 psychology (2006) 3(2):77-101.

629 18. Yin RK. Qualitative Research from Start to Finish: Guilford publications (2015).

630 19. de Castro AB. 'Hierarchy of Controls': Providing a Framework for Addressing 631 Workplace Hazards. AJN The American Journal of Nursing (2003) 103(12):104.

632 20. Dehghani F, Omidi F, Yousefinejad S, Taheri E. The Hierarchy of Preventive 633 Measures to Protect Workers against the Covid-19 Pandemic: A Review. Work (2020) 634 67:771-7. doi: 10.3233/WOR-203330. 
medRxiv preprint doi: https://doi.org/10.1101/2022.01.28.22270013; this version posted January 29, 2022. The copyright holder for this preprint (which was not certified by peer review) is the author/funder, who has granted medRxiv a license to display the preprint in

It is made available under a CC-BY-NC-ND 4.0 International license .

Agility and Sustainability

635 21. Fleiss JL, Levin B, Paik MC. Statistical Methods for Rates and Proportions: john

636 wiley \& sons (2013).

637 22. Glasgow RE, Harden SM, Gaglio B, Rabin B, Smith ML, Porter GC, et al. Re-Aim

638 Planning and Evaluation Framework: Adapting to New Science and Practice with a 20-Year

639 Review. Front Public Health (2019) 7:64-. doi: 10.3389/fpubh.2019.00064.

640 23. Gaglio B, Shoup JA, Glasgow RE. The Re-Aim Framework: A Systematic Review of

641 Use over Time. American journal of public health (2013) 103(6):e38-e46. Epub 2013/04/18.

642 doi: 10.2105/AJPH.2013.301299.

643 24. King DK, Shoup JA, Raebel MA, Anderson CB, Wagner NM, Ritzwoller DP, et al.

644 Planning for Implementation Success Using Re-Aim and Cfir Frameworks: A Qualitative

645 Study. Front Public Health (2020) 8(59). doi: 10.3389/fpubh.2020.00059.

646 25. Damschroder LJ, Aron DC, Keith RE, Kirsh SR, Alexander JA, Lowery JC. Fostering 647 Implementation of Health Services Research Findings into Practice: A Consolidated

648 Framework for Advancing Implementation Science. Implementation Science (2009) 4(1):50.

649 doi: 10.1186/1748-5908-4-50.

650 26. Hlaing PH, Sullivan PE, Chaiyawat P. Application of Precede-Proceed Planning

651 Model in Transforming the Clinical Decision Making Behavior of Physical Therapists in

652 Myanmar. Front Public Health (2019) 7:114-. doi: 10.3389/fpubh.2019.00114.

653 27. Crosby R, Noar SM. What Is a Planning Model? An Introduction to Precede-Proceed.

654 Journal of Public Health Dentistry (2011) 71(s1):S7-S15. doi: 10.1111/j.1752-

655 7325.2011.00235.x.

656 28. Wierenga D, Engbers LH, Van Empelen P, Duijts S, Hildebrandt VH, Van Mechelen

657 W. What Is Actually Measured in Process Evaluations for Worksite Health Promotion

658 Programs: A Systematic Review. BMC public health (2013) 13:1190-. doi: 10.1186/1471-

659 2458-13-1190.

660 29. Nevedal AL, Reardon CM, Opra Widerquist MA, Jackson GL, Cutrona SL, White

661 BS, et al. Rapid Versus Traditional Qualitative Analysis Using the Consolidated Framework

662 for Implementation Research (Cfir). Implementation Science (2021) 16(1):67. doi:

663 10.1186/s13012-021-01111-5.

664 30. Houghton C, Meskell P, Delaney H, Smalle M, Glenton C, Booth A, et al. Barriers

665 and Facilitators to Healthcare Workers' Adherence with Infection Prevention and Control

666 (Ipc) Guidelines for Respiratory Infectious Diseases: A Rapid Qualitative Evidence

667 Synthesis. Cochrane Database Syst Rev (2020) 4(4):Cd013582. Epub 2020/04/22. doi:

668 10.1002/14651858.Cd013582.

669 31. Harris MA, Kirkham TL. Covid-19 Experiences, Ppe, and Health Concerns in

670 Toronto, Canada Bicycle Delivery Workers: Cross-Sectional Pilot Survey. Annals of Work

671 Exposures and Health (2021). doi: 10.1093/annweh/wxab024.

672 32. Ortiz-Prado E, Henriquez-Trujillo AR, Rivera-Olivero IA, Lozada T, Garcia-

673 Bereguiain MA. High Prevalence of Sars-Cov-2 Infection among Food Delivery Riders. A

674 Case Study from Quito, Ecuador. Science of The Total Environment (2021) 770:145225. doi:

675 https://doi.org/10.1016/j.scitotenv.2021.145225.

676 33. Bambra C, Riordan R, Ford J, Matthews F. The Covid-19 Pandemic and Health

677 Inequalities. Journal of Epidemiology and Community Health (2020) 74(11):964-8. doi:

678 10.1136/jech-2020-214401. 
medRxiv preprint doi: https://doi.org/10.1101/2022.01.28.22270013; this version posted January 29, 2022. The copyright holder for this preprint (which was not certified by peer review) is the author/funder, who has granted medRxiv a license to display the preprint in

It is made available under a CC-BY-NC-ND 4.0 International license .

Agility and Sustainability

679 34. Fearon E, Buchan IE, Das R, Davis EL, Fyles M, Hall I, et al. Sars-Cov-2 Antigen

680 Testing: Weighing the False Positives against the Costs of Failing to Control Transmission.

681 The Lancet Respiratory Medicine (2021) 9(7):685-7. doi: 10.1016/S2213-2600(21)00234-4.

682 35. Gibson O, Lisy K, Davy C, Aromataris E, Kite E, Lockwood C, et al. Enablers and

683 Barriers to the Implementation of Primary Health Care Interventions for Indigenous People

684 with Chronic Diseases: A Systematic Review. Implementation Science (2015) 10(1):71. doi:

685 10.1186/s13012-015-0261-X.

686 36. Ndejjo R, Wanyenze RK, Nuwaha F, Bastiaens H, Musinguzi G. Barriers and

687 Facilitators of Implementation of a Community Cardiovascular Disease Prevention

688 Programme in Mukono and Buikwe Districts in Uganda Using the Consolidated Framework

689 for Implementation Research. Implementation Science (2020) 15(1):106. doi:

690 10.1186/s13012-020-01065-0.

691 37. Welby-Everard P, Quantick O, Green A. Emergency Preparedness, Resilience and

692 Response to a Biological Outbreak. BMJ Military Health (2020) 166(1):37. doi:

693 10.1136/jramc-2019-001323.

694 38. Patel A, D'Alessandro MM, Ireland KJ, Burel WG, Wencil EB, Rasmussen SA.

695 Personal Protective Equipment Supply Chain: Lessons Learned from Recent Public Health

696 Emergency Responses. Health Security (2017) 15(3):244-52.

697 39. Means AR, Kemp CG, Gwayi-Chore M-C, Gimbel S, Soi C, Sherr K, et al.

698 Evaluating and Optimizing the Consolidated Framework for Implementation Research (Cfir)

699 for Use in Low- and Middle-Income Countries: A Systematic Review. Implementation

$700 \quad$ Science (2020) 15(1):17. doi: 10.1186/s13012-020-0977-0.

701 40. Petherick A, Goldszmidt R, Andrade EB, Furst R, Hale T, Pott A, et al. A Worldwide

702 Assessment of Changes in Adherence to Covid-19 Protective Behaviours and Hypothesized

703 Pandemic Fatigue. Nature Human Behaviour (2021) 5(9):1145-60. doi: 10.1038/s41562-021-

704 01181-x.

705 41. Brewer NT, Chapman GB, Gibbons FX, Gerrard M, McCaul KD, Weinstein ND.

706 Meta-Analysis of the Relationship between Risk Perception and Health Behavior: The

707 Example of Vaccination. Health Psychology (2007) 26(2):136-45. doi: 10.1037/0278-

$708 \quad 6133.26 .2 .136$.

709 42. McDowell CP, Herring MP, Lansing J, Brower C, Meyer JD. Working from Home

710 and Job Loss Due to the Covid-19 Pandemic Are Associated with Greater Time in Sedentary

711 Behaviors. Front Public Health (2020) 8(750). doi: 10.3389/fpubh.2020.597619.

712 43. Gemine R, Davies GR, Tarrant S, Davies RM, James M, Lewis K. Factors Associated

713 with Work-Related Burnout in Nhs Staff During Covid-19: A Cross-Sectional Mixed

714 Methods Study. BMJ Open (2021) 11(1):e042591. doi: 10.1136/bmjopen-2020-042591.

715 44. Matsuo T, Taki F, Kobayashi D, Jinta T, Suzuki C, Ayabe A, et al. Health Care

716 Worker Burnout after the First Wave of the Coronavirus Disease 2019 (Covid-19) Pandemic

717 in Japan. Journal of Occupational Health (2021) 63(1):e12247. doi:

718 https://doi.org/10.1002/1348-9585.12247.

719 45. Leo CG, Sabina S, Tumolo MR, Bodini A, Ponzini G, Sabato E, et al. Burnout among 720 Healthcare Workers in the Covid 19 Era: A Review of the Existing Literature. Front Public

721 Health (2021) 9(1661). doi: 10.3389/fpubh.2021.750529. 
medRxiv preprint doi: https://doi.org/10.1101/2022.01.28.22270013; this version posted January 29, 2022. The copyright holder for this preprint (which was not certified by peer review) is the author/funder, who has granted medRxiv a license to display the preprint in It is made available under a CC-BY-NC-ND 4.0 International license.

Agility and Sustainability

722

723

724

46. Beckman KL, Monsey LM, Archer MM, Errett NA, Bostrom A, Baker MG. Health and Safety Risk Perceptions and Needs of App-Based Drivers During Covid-19. Am J Ind Med n/a(n/a). doi: https://doi.org/10.1002/ajim.23295. 
Table 1 HoC analysis - COVID-19 RMMs implemented by the logistics companies for delivery workers

\begin{tabular}{|c|c|c|c|c|c|}
\hline HoC/Measures & Food 1 & Parcel 1 & Parcel 2 & Large 1 & Large 2 \\
\hline \multicolumn{6}{|c|}{ 1. Elimination: Physically remove risk of workplace infection } \\
\hline \multicolumn{6}{|c|}{\begin{tabular}{|l|l|l|l} 
None practical & & & \\
\end{tabular}} \\
\hline \multicolumn{6}{|c|}{ 2. Substitution: Replace work procedures that create work contact with ones that do not } \\
\hline Contact-free delivery & + & ++ & ++ & + & + \\
\hline \multicolumn{6}{|c|}{ 3. Engineering Controls: Isolate workers from work contact } \\
\hline Establish exclusion zones & & & & + & \\
\hline Extra car hiring & & & & $\begin{array}{l}\text { Discussed but not } \\
\text { adopted }\end{array}$ & + March-June 2020 a \\
\hline Install physical barriers & & + & + & + & + \\
\hline Re-layout workplace & & + & + & + & 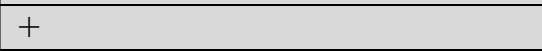 \\
\hline Restricted or discontinued services & & $\begin{array}{l}+\quad \text { Temporarily } \\
\text { suspended customer } \\
\text { collection }\end{array}$ & $\begin{array}{l}+\quad \text { Temporarily } \\
\text { suspended customer } \\
\text { collection }\end{array}$ & $\begin{array}{lr}+ & \text { Installation } \\
\text { service } & \text { suspended } \\
\text { March-May } 2020\end{array}$ & $\begin{array}{l}+\mathrm{RoC}^{\mathrm{b}} \text { suspended March-May } \\
2020 \text {; Initially failed deliveries if } \\
\text { customers reported symptomatic } \\
\text { or self-isolating }\end{array}$ \\
\hline Ventilation in buildings & & $\begin{array}{l}\text { Believed lack of } \\
\text { airflow in winter } \\
\text { was a cause of } \\
\text { outbreaks }\end{array}$ & Deemed sufficient & Deemed sufficient & + Open windows \\
\hline \multicolumn{6}{|c|}{ 4. Administrative controls: Change the way of working to reduce work contact } \\
\hline Pairs and bubbles (staff cohorts) & & + & + & + & + \\
\hline Social distancing & & + & + & + & + \\
\hline $\begin{array}{l}\text { Self-isolation (if symptomatic, tested } \\
\text { positive or close contact) }\end{array}$ & + & + & + & + & + \\
\hline Staggered working & & & + & + & + \\
\hline Ventilation in shared vehicles & & & & + Open windows & $\begin{array}{l}+ \text { Instructed windows } 1 / 3 \text { down } \\
\text { and recirculation turned off }\end{array}$ \\
\hline Hygiene measures & + & + & + & + & ++ \\
\hline Information Instruction \& Training (IIT) & + & + & + & + & + \\
\hline Working with industry and authorities & + & + & + & + & + \\
\hline Mental health support & & + & & + & + \\
\hline Compliance behaviour monitoring & + & + & + & + & + \\
\hline
\end{tabular}




\begin{tabular}{|c|c|c|c|c|c|}
\hline HoC/Measures & Food 1 & Parcel 1 & Parcel 2 & Large 1 & Large 2 \\
\hline Workplace contact tracing & & + & + & + & + \\
\hline Workplace infection monitoring & & + & + & + & 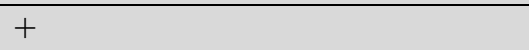 \\
\hline Workplace testing & & $\begin{array}{l}+ \text { Deployed 3rd } \\
\text { party testing at sites } \\
\text { had outbreaks }\end{array}$ & $\begin{array}{l}\text { Had concerns about } \\
\text { regular workplace } \\
\text { LFD }^{c} \text { testing }\end{array}$ & $\begin{array}{l}\text { Had concerns about } \\
\text { regular workplace } \\
\text { LFD testing }\end{array}$ & $\begin{array}{l}\text { Some sites used LFD for } \\
\text { warehouse staff }\end{array}$ \\
\hline Disciplinary action & & + & & + & \\
\hline \multicolumn{6}{|c|}{ 5. Personal protection: Protect workers with certain equipment, depending on expert risk assessment ${ }^{\mathrm{d}}$} \\
\hline Face coverings & + & + & + & + & + \\
\hline Gloves & + & + & & + & \\
\hline
\end{tabular}


Table 2 Rapid response process: COVID-19 - Logistics sector, adapted for evaluating a range of RMMs

\begin{tabular}{|c|c|c|c|c|}
\hline Domain & $\begin{array}{l}\text { Key } \\
\text { characteristics }\end{array}$ & Illustrations & Barriers & Facilitators \\
\hline \multirow[t]{3}{*}{$\begin{array}{l}\text { Intervention } \\
\text { characteristics }\end{array}$} & $\begin{array}{l}\text { Source of } \\
\text { interventions }\end{array}$ & $\begin{array}{l}\text { Whether the interventions are perceived as externally or } \\
\text { internally developed }\end{array}$ & $\begin{array}{l}\text { Unclear or changing } \\
\text { government guidance }\end{array}$ & $\begin{array}{l}\text { Capacity to develop } \\
\text { interventions internally }\end{array}$ \\
\hline & $\begin{array}{l}\text { Evidence } \\
\text { Strength \& } \\
\text { Quality }\end{array}$ & $\begin{array}{l}\text { Whether data are collected about the effectiveness of the } \\
\text { interventions and how the quality and validity of evidence are } \\
\text { perceived }\end{array}$ & $\begin{array}{l}\text { Shortage of testing } \\
\text { capacity and supply }\end{array}$ & \\
\hline & Costs & $\begin{array}{l}\text { Direct costs of the interventions and costs associated with } \\
\text { implementing the interventions including investment, supply, } \\
\text { and opportunity costs. }\end{array}$ & $\begin{array}{l}\text { High direct and } \\
\text { associated costs }\end{array}$ & \\
\hline \multirow[t]{3}{*}{$\begin{array}{l}\text { External } \\
\text { environment }\end{array}$} & $\begin{array}{l}\text { Prioritization of } \\
\text { safety }\end{array}$ & $\begin{array}{l}\text { The extent to which workers and customers' safety are } \\
\text { prioritized by the organization and other external actors, such } \\
\text { as the government. }\end{array}$ & & \\
\hline & Collaborations & $\begin{array}{l}\text { The degree to which an organization is collaborating with other } \\
\text { external organizations }\end{array}$ & & $\begin{array}{l}\text { Localized government } \\
\text { support }\end{array}$ \\
\hline & External pressure & $\begin{array}{l}\text { External pressure to enact a rapid response, such as } \\
\text { government mandates or peer pressure i.e., other organizations } \\
\text { have already implemented interventions }\end{array}$ & & $\begin{array}{l}\text { Overwhelming } \\
\text { external mandates }\end{array}$ \\
\hline \multirow[t]{4}{*}{$\begin{array}{l}\text { Organizational } \\
\text { setting }\end{array}$} & $\begin{array}{l}\text { Effective } \\
\text { communications }\end{array}$ & $\begin{array}{l}\text { How the effectiveness and quality of communications are } \\
\text { perceived }\end{array}$ & $\begin{array}{l}\text { Diversified language } \\
\text { and cultural } \\
\text { backgrounds. }\end{array}$ & $\begin{array}{l}\text { Effective } \\
\text { communication }\end{array}$ \\
\hline & Safety culture & $\begin{array}{l}\text { Norms, values, and basic assumptions about safety in the } \\
\text { organization. }\end{array}$ & & \\
\hline & $\begin{array}{l}\text { Implementation } \\
\text { climate }\end{array}$ & $\begin{array}{l}\text { The internal tension for change and the extent to which use of } \\
\text { the interventions will be rewarded, supported, and expected } \\
\text { within the organization. }\end{array}$ & & $\begin{array}{l}\text { Financial support for } \\
\text { self-isolation }\end{array}$ \\
\hline & $\begin{array}{l}\text { Leadership } \\
\text { commitment }\end{array}$ & $\begin{array}{l}\text { Commitment and involvement of leaders and managers with } \\
\text { the implementation }\end{array}$ & & Leadership support \\
\hline
\end{tabular}




\begin{tabular}{|c|c|c|c|c|}
\hline Domain & $\begin{array}{l}\text { Key } \\
\text { characteristics }\end{array}$ & Illustrations & Barriers & Facilitators \\
\hline \multirow[t]{4}{*}{$\begin{array}{l}\text { Implementation } \\
\text { process }\end{array}$} & Rapid response & $\begin{array}{l}\text { The degree to which the interventions are rapidly developed } \\
\text { and implemented without planning in advance }\end{array}$ & & \\
\hline & Full engagement & $\begin{array}{l}\text { Engaging appropriate individuals in the implementation of the } \\
\text { interventions through a combined strategy of social marketing, } \\
\text { education, role modelling, training, and other similar activities. }\end{array}$ & & \\
\hline & Strong execution & $\begin{array}{l}\text { Carrying out or accomplishing the implementation according } \\
\text { to plan }\end{array}$ & & \\
\hline & $\begin{array}{l}\text { Continuous } \\
\text { reflecting \& } \\
\text { evaluating }\end{array}$ & $\begin{array}{l}\text { Continuous risk assessment and learning, accompanied with } \\
\text { regular quantitative and qualitative feedback about the progress } \\
\text { and quality of implementation }\end{array}$ & & \\
\hline Sustainability & $\begin{array}{l}\text { Potential long- } \\
\text { term effects }\end{array}$ & $\begin{array}{l}\text { Any possible long-term effects when rapid responses have } \\
\text { lasted longer than expected }\end{array}$ & & \\
\hline
\end{tabular}

${ }^{\mathrm{i}}$ https://www.hse.gov.uk/coshh/detail/goodpractice.htm;

https://www.hse.gov.uk/construction/lwit/assets/downloads/hierarchy-risk-controls.pdf 